\title{
PRZEPISY KANCELARYJNE MINISTERSTWA ROLNICTWA I REFORM ROLNYCH W WARSZAWIE Z GRUDNIA 1945 ROKU. PRÓBA WDROŻENIA BEZDZIENNIKOWEGO SYSTEMU PRACY KANCELARYJNEJ
}

\section{Słowa kluczowe}

Ministerstwo Rolnictwa i Reform Rolnych w Warszawie 1945-1948, kancelaria Ministerstwa Rolnictwa i Reform Rolnych w Warszawie 1945-1948, kancelaria urzędów centralnych w Polsce 1945-1948, kancelaria w Polsce 1945-1948, biurowość w Polsce 1945-1948

\section{Keywords}

Ministry of Agriculture and Agricultural Reforms in Warsaw 1945-1948, office of the Ministry of Agriculture and Agricultural Reforms in Warsaw 1945-1948, bureaucracy

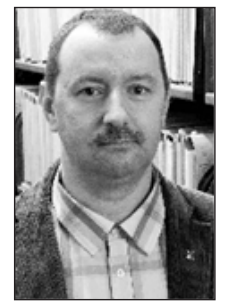

Adam Grzegorz Dąbrowski, doktor nauk humanistycznych z zakresie historii, od 1995 r. pracownik Archiwum Akt Nowych w Warszawie, obecnie starszy kustosz w Oddziale III Ewidencji i Przechowywania Zasobu. Jego zainteresowania naukowe koncentrują się głównie na zagadnieniach związanych z pracą zawodową (teoria i metodyka pracy archiwalnej, źródłoznawstwo, dzieje kancelarii polskiej XX wieku). Autor wielu tekstów naukowych publikowanych na łamach periodyków historyczno-archiwalnych. Współautor czterech wydawnictw źródłowych. E-mail: adamo@poczta.onet.pl ORCID ID: 0000-0003-4258-2435 
of central offices in Poland 1945-1948, bureaucracy in Poland 1945-1948, offices in Poland 1945-1948

\section{Streszczenie}

Ministerstwo Rolnictwa i Reform Rolnych utworzone zostało na mocy ustawy Krajowej Rady Narodowej z dnia 31 grudnia 1944 r. o powołaniu Rządu Tymczasowego Rzeczypospolitej Polskiej. Zakres kompetencji merytorycznych wywodził się jeszcze z okresu dwudziestolecia międzywojennego - był to więc całokształt zagadnień, dotyczących rolnictwa w Polsce, hodowli, oświaty rolniczej na szczeblu niższym i średnim, doświadczalnictwa rolniczego, weterynarii, melioracji, regulacji i utrzymania rzek i kanałów, przemysłu rolnego oraz zarząd nieruchomości ziemskich. Ministerstwo Rolnictwa i Reform Rolnych zniesione zostało na mocy zapisów ustawy z dnia 26 maja 1951 r. o organizacji władz naczelnych w dziedzinie rolnictwa.

W początkowym okresie kancelaria Ministerstwa funkcjonowała oczywiście również w oparciu o ogólne regulacje, obowiązujące w pracy biurowej Polskiego Komitetu Wyzwolenia Narodowego, jednak już z dniem 1 grudnia 1945 r. weszły w Ministerstwie w życie własne przepisy biurowe. Kancelaria ogólna Ministerstwa nie prowadziła żadnych pomocy ewidencyjnych, rozdzielała tylko wpływającą do urzędu korespondencję do poszczególnych departamentów i samodzielnych biur, według ich kompetencji merytorycznych. W departamentach i pozostałych samodzielnych komórkach następowała rejestracja w pomocy ewidencyjnej, nazwanej rejestrem (który pełnił rolę tradycyjnego dziennika podawczego), prowadzonej wspólnie dla wszystkich wydziałów danego departamentu. Dopiero w tych wydziałach następowała właściwa rejestracja w spisie spraw wydziału i nadanie oznaczenia symbolem wynikającym z rzeczowego strukturalnego wykazu akt danej komórki. W efekcie więc już od 1945 r. kancelaria Ministerstwa opierała swoje funkcjonowanie na nowoczesnym systemie rejestracji spraw nie w dzienniku podawczym (ten był wprawdzie stosowany, ale tylko to wstępnego ewidencjonowania korespondencji), a w oparciu o rzeczowy wykaz akt.

\section{Summary}

Office regulations of the Ministry of Agriculture and Agricultural Reforms in Warsaw from December 1945. An attempt to implement a journal-free system of office work

The Ministry of Agriculture and Agricultural Reforms was established by the Act of the State National Council of December 31, 1944 on the establishment of the Provisional Government of the Republic of Poland. The scope of its competences dates back to the interwar period - so it was the entirety of issues related to agriculture in Poland, breeding, agricultural education at the lower and middle level, agricultural experimentation, veterinary, melioration, regulation and maintenance of rivers and canals, agricultural industry and real estate management. The Ministry of Agriculture and Agricultural Reforms was abolished under the provisions of the Act of May 26, 1951 on the organization of supreme authorities in the field of agriculture. 
In the initial period, the Ministry's office, of course, also operated on the basis of general regulations applicable to the office work of the Polish Committee of National Liberation, but already on December 1, 1945 separate office regulations entered into force in the Ministry. The general office of the Ministry did not provide any record aids, it only distributed the correspondence received by the office to individual departments and independent offices, according to their competences. In the departments and other independent units, registration was carried out in a record-keeping aid, called the register (which served as a traditional correspondence journal), kept jointly for all units of a given department. It was only in these units that the proper registration in the list of the unit's affairs took place and the designation was given with a symbol resulting from the substantive structural records scheme of a given unit. As a result, since 1945 the Ministry's office based its operation on a modern system of registration of cases not in the correspondence journal (this was indeed used, but only for initial recording of correspondence), but on the basis of a substantive records scheme.

$\mathbb{M}$ inisterstwo Rolnictwa i Reform Rolnych utworzone zostało na mocy ustawy Krajowej Rady Narodowej z dnia 31 grudnia 1944 r. o powołaniu Rządu Tymczasowego Rzeczypospolitej Polskiej ${ }^{1}$. Jego poprzednikiem był Resort Rolnictwa i Reform Rolnych Polskiego Komitetu Wyzwolenia Narodowego (powołanego do życia na mocy zapisów ustawy Krajowej Rady Narodowej z dnia 21 lipca 1944 r. o utworzeniu Polskiego Komitetu Wyzwolenia Narodowego²). Zakres kompetencji merytorycznych wywodził się jeszcze z okresu dwudziestolecia międzywojennego, określony został przede wszystkim zapisami ustawy z dnia 11 sierpnia 1923 r. o zakresie działania Ministra Reform Rolnych i organizacji urzędów i komisji ziemskich ${ }^{3}$. Był to więc całokształt zagadnień, dotyczących rolnictwa w Polsce, hodowli, oświaty rolniczej na szczeblu niższym i średnim, doświadczalnictwa rolniczego, weterynarii, melioracji, regulacji i utrzymania rzek i kanałów, przemysłu rolnego oraz zarząd nieruchomości ziemskich. Wydaje się jednak, iż w omawianym tu okresie na plan pierwszy wysuwało się zagadnienie przebudowy ustroju rolnego państwa polskiego (określanego potocznie mianem reformy rolnej), które to zadanie na ministra rolnictwa i reform rolnych nałożyły zapisy dekretu Polskiego Komitetu Wyzwolenia Narodowego z dnia 6 września 1944 r. o przeprowadzeniu reformy rolnej ${ }^{4}$. Reforma rolna - jako jeden z kluczowych elementów przebudowy ustroju

1 „Dziennik Ustaw Rzeczypospolitej Polskiej” (dalej Dz. U.), 1944, nr 19, poz. 99.

2 Dz. U. 1944, nr 1, poz. 1.

${ }^{3}$ Dz. U. 1923, nr 90, poz. 706.

4 Dz. U. 1944, nr 4, poz. 17. 
gospodarczego państwa (którego drugim punktem była nacjonalizacja przemysłu, oraz walka o przejęcie i utrwalenie władzy politycznej przez komunistów, nielicznych i cieszących się znikomym poparciem w społeczeństwie) stanowiła wówczas istotny czynnik, kształtujący sytuację wewnętrzną państwa polskiego ${ }^{5}$.

Ministerstwo Rolnictwa i Reform Rolnych zniesione zostało na mocy zapisów ustawy z dnia 26 maja $1951 \mathrm{r}$ o organizacji władz naczelnych w dziedzinie rolnictwa - powołany wtedy został urząd ministra państwowych gospodarstw rolnych, zaś urząd ministra rolnictwa i reform rolnych przekształcony w urząd ministra rolnictwa ${ }^{6}$.

Kierowanie polityką rolną państwa wymagało sprawnego i skutecznego nadzoru funkcjonowania aparatu podległego ministrowi rolnictwa i reform rolnych - w tym wymiany informacji (korespondencji) zarówno pomiędzy centralą ministerstwa a podległymi mu placówkami w terenie, jak i właściwego obiegu pism (czyli zawartych w nich informacji) w samej centrali urzędu ministerstwa skarbu, zapewnianego przez prawidłową pracę komórek obsługi kancelaryjnej urzędu. Niniejszy tekst stanowi właśnie próbę analizy funkcjonowania kancelarii centrali Ministerstwa Rolnictwa i Reform Rolnych w Warszawie w latach 1945-1948 (czyli do momentu ukazania się okólnika prezesa rady ministrów z dnia 5 lutego 1948 r. w sprawie uporządkowania systemu kancelaryjnego w ministerstwach i innych urzędach centralnych), stanowiąc kolejny przyczy-

${ }^{5}$ Szerzej na temat przebiegu i rezultatów reformy rolnej na ziemiach polskich w ujęciu ogólnym: H. Słabek, Dzieje polskiej reformy rolnej 1944-48, Warszawa 1972; tenże, Polityka agrarna PPR: geneza, realizacja, konsekwencje, Warszawa 1978; Z kolei zagadnienie to w ujęciu dla poszczególnych rejonów (przykładowo) omówione zostało w pracach: H. Słabek, Przebudowa ustroju rolnego w Wielkopolsce i na Pomorzu 1945-1948, Poznań 1968; S. Iwaniak, Reforma rolna $w$ województwie kieleckim $w$ latach 1944-1945, Warszawa 1975; C. Brzoza, Reforma rolna w województwie krakowskim (1945-1948), Wrocław 1988; M. Kozaczka, Reforma rolna $w$ ordynacji przeworskiej w latach 1944-1945, „Rocznik Przemyski” 1999, z. 4, s. 117-126; tenże, Reforma rolna w ordynacji zamojskiej 1944-1945, „Prace Historyczno-Archiwalne” 2000, t. 9, s. 173-185; tenże, Reforma rolna w ordynacji kozłowieckiej 1944-1945, „Rocznik Historyczno-Archiwalny” 2001, t. 15, s. 95-107; K. Kubisiak, Reforma rolna $w$ województwie łódzkim, „Piotrkowskie Zeszyty Historyczne" 2004, t. 6, s. 239-250; A. Wielgosz, Reforma rolna w powiecie łukowskim 1944-1946, „Roczniki Wyższej Szkoły Biznesu i Administracji w Łukowie” 2008, nr 4, s. 409-431; P. Stasiak, Reforma rolna w powiecie kutnowskim. Część 1: rok 1945, „Kutnowskie Zeszyty Regionalne", t. 13, 2009, s. 89-114; tenże, Reforma rolna w powiecie kutnowskim. Część 2: spółdzielnie produkcyjne do 1952r., „Kutnowskie Zeszyty Regionalne” 2010, t. 14, s. 147-202; G. Pękul, Reforma rolna w gminie Łochów, „Rocznik Historyczny Muzeum Historii Polskiego Ruchu Ludowego" 2013, nr 29, s. 113-128.

${ }^{6}$ Dz. U. 1951, nr 30, poz. 236. 
nek do badań nad organizacją i funkcjonowaniem kancelarii urzędów centralnych w Polsce po 1945 r. $^{7}$ Analiza ta dokonana została na podstawie zapisów w zachowanych normatywach biurowych Ministerstwa oraz jego archiwaliów, na których najczytelniej i najpełniej figurują ślady poszczególnych czynności kancelaryjnych (zaś w przypadkach nie odnalezienia normatywów biurowych urzędu - analiza dokonana mogła być jedynie na ich podstawie).

Podstawą źródłową niniejszego tekstu są archiwalia z zasobu Archiwum Akt Nowych w Warszawie: Resortu Rolnictwa i Reform Rolnych z 1944 r. (stanowią fragment zespołu akt Polskiego Komitetu Wyzwolenia Narodowego) oraz Ministerstwa Resortu Rolnictwa i Reform Rolnych z lat 1945-1951. Te pierwsze zachowane niestety bardzo fragmentarycznie, w ilości zaledwie 44 teczek, drugie zaś w ilości 5065 teczek (choć ich szczegółowa analiza również wskazuje wyraźnie na niekompletny stan zachowania archiwaliów niektórych komórek organizacyjnych urzędu, których to archiwaliów także brak w zespole akt sukcesora - Ministerstwa Rolnictwa z lat 1951-1981).

Nie udało się odnaleźć ogólnych normatywów kancelaryjnych Polskiego Komitetu Wyzwolenia Narodowego czy normatywów jego Resortu Rolnictwa i Reform Rolnych, stąd pewne informacje o ich biurowości można zaczerpnąć jedynie poprzez analogie z innymi komórkami organizacyjnymi Komitetu oraz

7 Funkcjonowaniu kancelarii urzędów centralnych państwa polskiego w pierwszych latach okresu powojennego poświęcono w literaturze naukowej jak dotąd tylko kilka opracowań o charakterze ogólnym (W. Klonowska, Próby usprawnienia kancelarii (biurowości) urzędów administracji centralnej w latach 1945-1952, „Acta Universitatis Nicolai Copernici", Historia, t. VIII, 1973, s. 189-202; R. Degen, Sposoby usprawnienia pracy biurowej w polskich urzędach $w$ latach 1945-1950, [w:] Dzieje biurokracji na ziemiach polskich, t. I, red. A. Górak, I. Łuć, D. Magier, Lublin - Siedlce 2008, s. 537-550), przyczynków (A. G. Dąbrowski, Przepisy kancelaryjne Ministerstwa Administracji Publicznej z lat 1945-1950, „Teki Archiwalne. Seria Nowa” 2003, t. 7 (29), s. 63-74; R. Degen, O usprawnienie kancelarii Ministerstwa Administracji Publicznej. Projekt Mariana Cieszyńskiego z grudnia 1947 roku, „Krakowski Rocznik Archiwalny” 2005, t. 11, s. 203-215; Z. Krupska, Zarządzanie dokumentacją aktowq w naczelnych organach bezpieczeństwa państwa i porządku publicznego w latach 1944-1990, [w:] W kręgu „teczek”. Z badań nad zasobem i funkcjami archiwum Instytutu Pamięci Narodowej, red. J. Bednarek, P. Perzyna, Łódź - Toruń 2006, s. 115-128; A. G. Dąbrowski, Przepisy kancelaryjne Ministerstwa Ziem Odzyskanych z lat 1945-1949, „Archeion” 2016, t. 117, 2016, s. 387-405; tenże, Kancelaria Ministerstwa Skarbu w Warszawie w latach 1944-1950, „Archiwa - Kancelarie - Zbiory” 2018, nr 9 (11), s. 149-178) czy też fragmentów prac monograficznych (A. Barszcz, Prezydium Rady Ministrów i Urząd Rady Ministrów jako wytwórcy państwowego zasobu archiwalnego (1945-1996), Warszawa 2014, s. 183-196; T. Filipczak, Kancelaria Sejmu i Rady Państwa oraz archiwum w latach [1944] 1952-1989, Warszawa 2015, s. 17-43, 82-103, 173-182). 
z postaci widniejących na dokumentach znaków kancelaryjnych (pieczęci i zapisów poczynionych $w$ ich rubrykach). Jednak i ta analiza wyraźnie wskazuje, iż poszczególne resorty stosowały odmienne reguły na oznaczanie wchodzących i wychodzących pism spraw bieżących czy spraw zakończonych. Niestety, stan zachowania archiwaliów Resortu Rolnictwa i Reform Rolnych umożliwia dokonanie takiej analizy tylko w przypadku jego Wydziału Przebudowy Ustroju Rolnego oraz częściowo Wydziału Produkcji Rolnej, bowiem tylko na pismach tegoż Wydziału znajdują się przydatne do stosownej analizy oznaczenia. Dokumenty innych komórek posiadają oczywiście również swoje oznaczenie, jednak trudno na ich podstawie wyciągnąć realne wnioski

Udało się odnaleźć tylko jedno pismo z początkowego okresu działania Resortu Rolnictwa i Reform Rolnych (z sierpnia 1944 r.), na którym jest naniesiony znak pisma, w postaci „Nr. R - 48 / 44”. Poprzez wspomniane analogie z innymi komórkami organizacyjnymi Polskiego Komitetu Wyzwolenia Narodowego można w dużą dozą pewności uznać, iż symbol „R” oznaczał Resort Rolnictwa i Reform Rolnych, liczba "48” to kolejna pozycja z dziennika podawczego Komitetu ( $w$ tym okresie - wspólnego dla wszystkich komórek organizacyjnych tego urzędu), liczba zaś "44” to dwie ostatnie cyfry daty rocznej. Z czasem - to również stwierdzić można poprzez porównanie z innymi komórkami Komitetu - poszczególne resorty uruchamiały własne kancelarie, dla obsługi własnej korespondencji.

Na pismach wspomnianego wyżej Wydziału Przebudowy Ustroju Rolnego w połowie listopada $1944 \mathrm{r}$. pojawiają się oznaczenia, stosowane w takiej postaci do przekształcenia resortu w Ministerstwo Rolnictwa i Reform Rolnych - pierwsze na piśmie z 14 listopada: „Nr 1/U.R./P/3”, gdzie „U.R.” to oznaczenie właśnie tego Wydziału, „P” to albo oznaczenie oddziału w strukturze

${ }^{8}$ I trudno w tym miejscu osądzić, czy w innych komórkach organizacyjnych Resortu obowiązywały takie same zasady, ale nie były po prostu stosowane, czy też posiadały przepisy własne, które również nie musiały być przestrzegane... Jednak spojrzenie na szerszą perspektywę - tu: całokształt ówczesnej sytuacji politycznej kraju - pozwala wysnuć przypuszczenie, iż właśnie w przypadku tej komórki organizacyjnej Resortu (odpowiedzialnej za przebieg reformy rolnej) na wybór systemu prowadzenia akt mogła decydować szczególna troska o dokumentację, dotyczącą reformy rolnej. A generalnie, nie można wymagać przestrzegania (czy w ogóle - posiadania jakichś) przepisów kancelaryjnych, skoro jeszcze w połowie października 1944r. Resort nie dysponował maszynami do pisania, w ilości dostatecznej dla bieżącej codziennej działalności; Archiwum Akt Nowych (dalej AAN), Polski Komitet Wyzwolenia Narodowego w Lublinie 1944 [1945-1953] (dalej PKWN), sygn. V/1, s. 14.

9 Tamże, sygn. V/4, s. 78. 
wydziałowej, albo oznaczenie jej referatu, cyfra „3” mogła oznaczać referat bądź jakąś grupę (typ) spraw, zaś cyfra „1” stanowiła pierwszą zarejestrowana w ten sposób sprawę ${ }^{10}$. Wielkość tych ostatnich zwiększa się wraz z datacją kolejnych pism $^{11}$. Z kolei w Wydziale Produkcji Rolnej stosowano oznaczenia, wynikające z zapisów wykazu oznaczeń akt Wydziału, noszącego datę 31 października 1944 r. Pisma tej komórki organizacyjnej miały być oznaczane symbolami o postaci „PR/I/1”, gdzie „PR” to oznaczenie całego Wydziału, cyfry rzymskie miały oznaczać jego oddziały, zaś cyfry arabskie - inspektoraty (referaty) ${ }^{12}$. Wykaz ten został niebawem uzupełniony zapisem pisma okólnego z dnia 20 listopada 1944 r., w którym dodano symbol dla pism spraw ogólnych całego Wydziału „PR/Og"13. Oznaczenia takie rzeczywiście widnieją na zachowanych pismach ${ }^{14}$. Analogicznie oznaczane były też pisma Wydziału Wodno-Melioracyjnego „WM/I/1/KM"15.

Na pismach pozostałych komórek organizacyjnych widnieją oznaczenia innej postaci. Składają się z symbolu komórki organizacyjnej oraz liczby, odpowiadającej zapewne jakąś grupę (typ) spraw, rozpatrywanych przez owe komórki przykładowo „BOrg.21”16, „B.Pr.10”17, „BKanc.53”18 czy też „Nr.BOrg.26”19. Oznaczenia tej postaci znajdują się na pojedynczych pismach wychodzących i wchodzących w teczkach, ale są też przypadki, kiedy jedno takie oznaczenie noszą wszystkie pisma w teczce (przykładowo „Bg.44”20 oraz „B.Org.29”21).

10 Tamże, sygn. V/19, s. 12.

11 Przykładowo: na piśmie z 20 listopada figuruje oznaczenie „Nr 8/U.R./P/1” (tamże, sygn. V/13, s. 204), na piśmie z dnia 21 listopada widnieje oznaczenie „13/U.R./P/2” (tamże, sygn. V/9, s. 97). Na piśmie z 18 grudnia widnieje „Nr. 61/U.R./P/2” (tamże, s. 77). Na piśmie z dnia 20 grudnia - „69/U.R./P/2” (tamże, sygn. V/19, s. 42), trudno jednak z powodu szczątkowego stanu zachowania akt w tym miejscu jednoznacznie stwierdzić, czy owa numeracja była wspólna dla pism wszystkich komórek organizacyjnych Wydziału, choć z ich analizy wynika, iż najprawdopodobniej mogło to mieć miejsce.

12 Tamże, sygn. V/1, s. 17.

13 Tamże, s. 18.

14 Przykładowo: „PR/I/7” (tamże, sygn. V/22, s. 71), czy „PR/III/3” (tamże, sygn. V/ /5, s. 1).

15 Tamże, sygn. V/2, s. 109; litery „KM” były zapewne inicjałami referenta merytorycznego, opracowującego dane pismo.

16 Tamże, sygn. V/4, s. 9.

17 Tamże, s. 82.

18 Tamże, s. 87.

19 Tamże, sygn. V/9, s. 73.

20 Tamże, sygn. V/31.

21 Tamże, sygn. V/38. 
Udało się odnaleźć również dwie oryginalna teczki z omawianego okresu. Jedną z nich opisano „Teczka No B.Org.24”, i zawiera ona pisma opatrzone takim samym oznaczeniem ${ }^{22}$. Druga z kolei posiada opis „Teczka No B.Kanc.51”, jednak w tym przypadku wewnątrz znajdują się różnie oznakowane pisma (najwięcej „B.Kanc.53”) ${ }^{23}$. Sugeruje to, iż oznaczenia w postaci symbolu komórki organizacyjnej oraz liczby pełniły funkcję zarówno znaku pisma spraw bieżących, jak i służyły do znakowania teczek z dokumentacją tych spraw w registraturze Resortu (z uwagi krótki czas funkcjonowania i na przekształcenie Resortu w samodzielny urząd ministerialny, do archiwum zakładowego teczki te w okresie od lipca do grudnia 1944 r. nie zdążyły zapewne być przekazane). Być może dotyczyło to także akt wydziałów Przebudowy Ustroju Rolnego, Produkcji Rolnej oraz Wodno-Melioracyjnego, jednak brak oryginalnych obwolut uniemożliwia zbadanie tego zagadnienia.

Oznaczenia kancelaryjne zachowały się też na pismach Wydziału Weterynaryjnego (Wydziału Weterynarii) z października i listopada 1944 r. Mają one postać „V/Org”24 oraz „V/3/b/8”25. Nie widać tu literowego symbolu Wydziału, być może w tym wypadku była nim cyfra „V”, a być może po prostu nie zapisano go i cyfra rzymska oznaczała oddział (dział) Wydziału, zaś kolejna cyfra arabska - inspektorat (referat), jak w przypadku wyżej opisanych oznaczeń pism innych wydziałów Komitetu ${ }^{26}$.

Na zachowanych pismach Resortu (noszących datację od września do końca jego istnienia) pojawiają się pieczątki wpływu, posiadające rubrykę tytułową „Resort Rolnictwa i Reform Rolnych P.K.W.N.” oraz pola: „Wydz...., Zał...., Dnia...., Przydział...., N...., K...., R....., Nr...."27. Pieczątka ta była więc rozbudowana, jednak na odnalezionych odciskach wypełnione są jedynie pola na wskazanie przydziału, liczby ewentualnych załączników, daty wpływu i oznaczenia sprawy, stąd też nie można nawet podać definicji wszystkich pół tej pieczęci. Bardzo sporadycznie pojawia się pieczątka kancelaryjna, zawierająca pola na zanotowanie dat otrzymania brudnopisu do przepisania, sporządzenia czystopisu,

22 Tamże, sygn. V/24.

23 Tamże, sygn. V/27.

24 AAN, Ministerstwo Rolnictwa i Reform Rolnych w Warszawie 1945-1951 (dalej MRiRR), sygn. 1237, nlb.

25 Tamże.

${ }^{26}$ W wyjaśnieniu tej kwestii nie jest pomocna analiza treści merytorycznej tak oznaczonych pism, bowiem oba oznaczenia widnieją na pismach dotyczących tworzenia i organizacji wewnętrznej katedr weterynarii na uczelniach wyższych.

27 Przykładowo - AAN, PKWN, sygn. V/4, s. 98. 
jego sprawdzenia i wysłania do adresata, wraz z rubrykami na podpis osoby odpowiedzialnej za daną czynność ${ }^{28}$.

Normatywy dotyczące pracy kancelaryjnej nowopowstałego Ministerstwa Rolnictwa i Reform Rolnych ogłoszone zostały pod koniec roku 1945, do tego momentu w urzędzie stosowano rozwiązania wypracowane jeszcze przez Resort Rolnictwa i Reform Rolnych Polskiego Komitetu Wyzwolenia Narodowego. Nadal więc używano pieczęci wpływu, posiadającej rubrykę tytułową „Resort Rolnictwa i Reform Rolnych P.K.W.N.” oraz pola: „Wydz...., Zał...., Dnia...., Przydział...., N...., K...., R...., Nr...."29. Dopiero kilka miesięcy później na dokumentach pojawiają się pieczątki wpływu innych wzorów - pierwsza posiadała wiersz tytułowy „Ministerstwo Rolnictwa i R.R” oraz rubryki: „Min..., Dept..., Data..., Przydział..., W..., R...., Załączników..., Nr..."30, druga miała wiersz nagłówkowy „Ministerstwo Rolnictwa i Reform Rolnych”, poniżej miejsce na wpisanie daty oraz pola: „Depar..., Wydz..., Ref..., Załącz..., Nr. dz...”’1.

Oznaczenia widniejące na pismach wychodzących z Ministerstwa oraz widniejące w stosownych rubrykach pieczątek wpływu miały postać zbliżoną do tych, figurujących na pismach z okresu sprzed 1 stycznia 1945 r. I tak w przypadku Departamentu Produkcji Rolnej oznaczenia miały postać - przykładowo „PR/I/Og”32, „PR/I/2”33, „PR/II/6”34, „PR/Adm/25d”35, „PR/1/XV/306”36 czy też „PR/I/12/839”37. Z kolei Departament Wodno-Melioracyjny stosował oznaczenia „WM-I-16”38, „WM-I-1-16”39 bądź „WM-I-10/TP”40. Departament Przebudowy Ustroju Rolnego oznaczał swoje pisma symbolami „929/U.R./P/2”41 albo „1192/UR/P/1”42. Rozbudowane oznaczenia stosowane były przez Departament

\footnotetext{
28 Przykładowo - tamże, sygn. V/6, s. 103.

${ }^{29}$ Przykładowo - AAN, MRiRR, sygn. 29, nlb.

30 Przykładowo - tamże, sygn. 117, s. 6.

31 Przykładowo - tamże, sygn. 31, s. 118.

32 Tamże, sygn. 29, nlb.

33 Tamże, sygn. 1073, nlb.

34 Tamże.

35 Tamże, sygn. 118, s. 60.

36 Tamże, sygn. 2935, nlb.

37 Tamże, sygn. 2936, nlb.

38 Tamże, sygn. 1072, nlb.

39 Tamże.

40 Tamże, sygn. 29, nlb.

41 Tamże, sygn. 2936, nlb.

42 Tamże, sygn. 79, s. 14.
} 
Oświaty Rolniczej: „WOR-2-I-2/10”43, „Nr.OR/VII/1a/3d/1589/45”44, „Nr.OR/ VII/1a/1590/45”45, „OR/VII/3/1780/45”46 czy „OR VII/3117/3ab/45”47. Wreszcie w Departamencie Weterynarii pisma oznaczano symbolami „V/3/a/1/2"48, „V/3/b/1/1059”49, „V/3/b/8/1107”50, „V/3/b/6/95”51, zaś Konsulent Ekonomiczny używał oznaczeń w postaci „Nr.K.Ek./206/45”52. Obok tradycyjnej pieczątki kancelaryjnej (z rubrykami na zapisanie dat otrzymania brudnopisu do przepisania, sporządzenia czystopisu, jego sprawdzenia i wysłania do adresata oraz miejscem na podpis osoby odpowiedzialnej za daną czynność), na pismach Ministerstwa pojawiała się w tym okresie także pieczątka w wersji uproszczonej: „Ministerstwo Rolnictwa i R. R., Ekspedycja, wysłano..." ${ }^{53}$

Najstarsze zachowane normatywy kancelaryjne Ministerstwa opatrzone zostały nagłówkiem „Ministerstwo Rolnictwa i Reform Rolnych. Instrukcja Kancelaryjna"54. Zachowane w aktach egzemplarze instrukcji nie posiadają daty dziennej, poprzedza je dokument, zatytułowany „Uzupełnienie Instrukcji Kancelaryjnej Ministerstwa Rolnictwa i Reform Rolnych", datowany na dzień 14 listopada 1945 r., w którym widnieje zapis o wejściu w życie właśnie z dniem 1 grudnia 1945 r. ${ }^{55}$ Dowodzi to, iż po opracowaniu, zatwierdzeniu i powieleniu tekstu instrukcji dostrzeżono konieczność naniesienia w nim drobnych uzupełnień, zawartych właśnie w tekście pisma z 14 listopada. Zasadniczy tekst był więc gotowy już wcześniej, jednak - jak już wspomniano - zachowane egzemplarze nie posiadają daty dziennej, a materiałów roboczych, dotyczących powstawania ostatecznej wersji tekstu nie udało się odnaleźć. Zapisy dokumentu powinny obowiązywać w Ministerstwie od dnia 1 grudnia 1945 r.

\footnotetext{
43 Tamże, sygn. 1073, nlb.

44 Tamże, sygn. 2836, s. 136.

45 Tamże, s. 143.

46 Tamże, sygn. 3208, nlb.

47 Tamże.

48 Tamże, sygn. 1237, nlb.

49 Tamże.

50 Tamże.

51 Tamże, sygn. 1238, s. 1.

52 Tamże, sygn. 2935, nlb; „konsulent” - przestarzale doradca.

53 Przykładowo - tamże, sygn. 31, s. 103.

54 Tamże, sygn. 249, s. 37-61.

55 Tamże, s. 35-36; informacja o datacji dokumentu na dzień 14 listopada 1945 r. widnieje także w tekście zarządzenia wewnętrznego z dnia 30 czerwca 1948r., wprowadzającego w życie zapisy nowej, chronologicznie kolejnej instrukcji kancelaryjnej Ministerstwa; tamże, sygn. 4997, s. 234.
} 
Przepisy składały się z dwunastu paragrafów (części), które uzupełniało piętnaście załączników ${ }^{56}$. Paragraf pierwszy dotyczył podziału czynności kancelaryjnych w urzędzie. Przyjmowanie wpływającej do Ministerstwa korespondencji, rozdział jej na komórki organizacyjne, sporządzanie czystopisów i ich ekspedycja oraz przechowywanie akt spraw załatwionych i niepotrzebnych do bieżącej działalności leżeć miało w kompetencjach kancelarii, która te zadania spełniała centralnie dla całego urzędu. W skład kancelarii wchodziły: biuro informacyjno-podawcze, oddział maszyn, ekspedycja i składnica akt. Wszelkie inne czynności kancelaryjne - w tym rejestracja - odbywać się miały w poszczególnych wydziałach (komórkach organizacyjnych), wykonywać je mieli - przy pomocy sekretarza wydziału i przydzielonego im personelu kancelaryjnego referenci merytoryczni, w zakresie załatwianych przez nich spraw. Drugi paragraf omawiał proces przyjmowania korespondencji w Ministerstwie, której całość (czyli nadchodząca za pośrednictwem poczty, wnoszona osobiście, telegraficznie i telefonicznie) miała być przekazywana do biura informacyjno-podawczego głównej kancelarii. Biuro to dokonywało także rozdziału korespondencji (omawiał to paragraf trzeci instrukcji), na podstawie zapisów statutu Ministerstwa i szczegółowego podziału czynności jego komórek organizacyjnych. Pisma adresowane imiennie i do rąk własnych - doręczane miały być według zalecenia nadawcy, korespondencja wartościowa oraz przekazy pieniężne - miały być przekazywane do działu kasowego Ministerstwa. Pozostała korespondencja po właściwym rozdzieleniu przekazywana była sekretarzom poszczególnych wydziałów urzędu, którzy następnie - zgodnie z podziałem czynności danego wydziału - doręczali pisma referentom merytorycznym.

Na wpływających pismach biuro informacyjno-podawcze umieszczać powinno odcisk pieczęci wpływu z mechanicznym datownikiem, określonym załącznikiem numer 1, posiadającej miejsce na odnotowanie symbolu wydziału Ministerstwa (rubrykę tę wypełniano w biurze informacyjno-podawczym), referenta oraz znaku sprawy. Na telegramach miano ponadto odnotowywać godzinę i minutę otrzymania. Z analizy archiwaliów urzędu wynika jednak, iż w praktyce nie stosowano pieczęci, opisanej w instrukcji. Nadal używano bowiem opisanej już wcześniej pieczątki wpływu, posiadającej wiersz nagłówkowy „Ministerstwo Rolnictwa i Reform Rolnych”, poniżej miejsce na wpisanie daty oraz pola: „Depar..., Wydz..., Ref..., Załącz..., Nr. dz..." (wzoru tego używano w latach 1945$-1947)^{57}$. Na dokumentach z 1947 r. pojawiła się już pieczęć wpływu nowego

56 Jednego z nich - załącznika nr 7 - nie udało się odnaleźć.

57 Przykładowo - AAN, MRiRR, sygn. 1491, s. 32. 
wzoru (stosowana także w 1948 r.), z nazwą „Ministerstwo Rolnictwa i Reform Rolnych" w wierszu tytułowym, datownikiem automatycznym poniżej oraz polami „Dep..., Wydz..., Zał..., Zn. akt...”58. Na niektórych dokumentach widnieje też inna pieczątka, świadcząca iż niektóre komórki organizacyjne Ministerstwa posiadały i stosowały w omawianym okresie - obok pieczęci wpływu kancelarii ogólnej urzędu - swoje własne pieczątki wpływu. Na pisma Biura Personalnego nanoszono niewielkich rozmiarów pieczęć, posiadającą napis nagłówkowy treści „Ministerstwo Rolnictwa i R. R., Biuro Personalne” oraz rubryki „Nr..., Data wpływu..., Akta..."59. Departament Finansowy (Ekonomiczny) stosował z kolei pieczątkę treści „Data wpływu..., L.dz..., Przydział...”, przy czym daty widniejące w stosownej rubryce tej pieczątki były chronologicznie późniejsze o kilka dni, niż daty widniejące w pieczęci wpływu kancelarii głównej urzędu ${ }^{60}$.

Treść paragrafu trzeciego została uzupełniona jednym z fragmentów wspomnianego już wyżej dokumentu, datowanego na dzień 14 listopada 1945 r. Uzupełnienie dotyczyło trybu rejestracji korespondencji ${ }^{61}$. Rejestracji dokonywać miały departamenty, we wspólnej dla wszystkich podległych im wydziałów pomocy ewidencyjnej, nazwanej rejestrem (określonym załącznikiem numer 3 zasadniczego tekstu normatywów biurowych Ministerstwa). Miał on postać księgi z rubrykami na zanotowanie: numeru porządkowego wpływu, daty wejścia pisma i daty wysłania odpowiedzi, nadawcy, daty i oznaczenia pisma nadawcy, opisu przedmiotu sprawy, przydziału danego pisma, opisu sposobu załatwienia, znaku akt. W wydziałach natomiast rejestrację prowadzić miano w pomocy ewidencyjnej, nazwanej spisem spraw (określonym załącznikiem numer 2 głównego tekstu przepisów kancelaryjnych Ministerstwa). On z kolei miał postać luźnych kart z rubrykami, pozwalającymi zanotować nazwę departamentu i wydziału, znak akt, bieżący rok kalendarzowy, tytuł akt, numer porządkowy pojedynczego wpływu, datę jego otrzymania, ewentualnego numeru z rejestru specjalnego, opis przedmiotu sprawy, uwag (w tej rubryce należało też zapisać dane referenta merytorycznego sprawy) oraz daty załatwienia. Po ostatecznych załatwieniu sprawy, sporządzeniu czystopisu odpowiedzi i uzyskaniu stosownych podpisów,

58 Przykładowo - tamże, sygn. 1459, nlb.

59 Przykładowo - tamże, sygn. 84, s. 1, 16, 56; znakowane tak pisma Biura Personalnego pochodzą z 1946 r., w późniejszym okresie pojawiają pieczątki tego samego typu także na pismach innych komórek Ministerstwa - odnaleziono je choćby na pismach z 1949 r. Departamentu Kontroli, oczywiście z napisem w wierszu nagłówkowym „Ministerstwo Rolnictwa i R. R., Departament Kontroli”; tamże, sygn. 784, s. 102, 118, 122.

60 Przykładowo - tamże, sygn. 27, s. 121, 127.

61 Tamże, sygn. 249, s. 35. 
uzupełnieniu departamentowych i wydziałowych pomocy ewidencyjnych całość dokumentacji sprawy należało przekazać do głównej kancelarii urzędu, która prowadzić miała ekspedycję wszystkich odpowiedzi.

Kolejny - czwarty - paragraf omawiał kwestię rejestracji spraw. Podstawę owej rejestracji - oraz oznaczania pism i przechowywania akt - powinien stanowić wykaz akt, ujmujący w jednorodne lub pokrewne przedmiotowo sprawy z zakresu działania danej komórki organizacyjnej urzędu. Sprawy te w pierwszej kolejności miały być dzielone na działy główne (grupy główne), oznaczane kolejnymi cyframi rzymskimi, następnie na poddziały, oznaczane kolejnymi cyframi arabskimi. Cyfry te stanowiły cechy rozpoznawcze poszczególnych kategorii spraw, a dokumentacji każdej kategorii spraw miała odpowiadać jedna pozycja z wykazu akt - czyli jedna teczka, oznaczona właśnie swoją cechą (znakiem akt). Każdą pojedynczą sprawę, rozpatrywaną w komórce organizacyjnej, należało odnotować we wspomnianym wyżej spisie spraw (prowadzonym odrębnie dla każdej teczki), a numer kolejnej pozycji spisu - łącznie ze znakiem akt - stanowił znak sprawy, którym należało opatrywać wszystkie pisma tej sprawy. Znak sprawy uzupełniać powinien skrót nazwy wydziału, rozpatrującego daną sprawę. Rejestracji na spisie podlegać miało tylko pierwsze pismo danej sprawy, każde kolejne pismo - należało oznaczać znakiem pisma wszczynającego ową sprawę. Spisy spraw należało prowadzić odrębnie dla każdego roku kalendarzowego i z początkiem nowego roku rozpoczynać wpisy od numeru „1”. Same zaś spisy przechowywane miały być w teczkach z dokumentami spraw bądź oddzielnie ${ }^{62}$.

Według instrukcji żadne inne pomoce kancelaryjne nie miały być prowadzone, jednak uczyniono od tej reguły wyjątki. Pierwszym był rejestr specjalny, przewidywany dla dokumentacji spraw wymagających - ze względu na swój charakter - odrębnej kontroli ${ }^{63}$. Pomoc ewidencyjna miała mieć postać opisanego wyżej załącznika numer 3 , zaś dla spraw wymagających nadania porządku alfabetycznego - formę skorowidza w postaci kartoteki. Jej kształt definiował załącznik numer 3a, posiadający rubryki na zapisanie: litery, pod którą zarejestrowane było pismo danej sprawy, nazwy wydziału, danych referenta tej sprawy, krótkiego opisu treści sprawy, znaku sprawy, numeru kolejnego wpływu w tej

${ }^{62}$ Omawiane przepisy nie precyzują kwestii technicznych ewentualnego trzymania spisów spraw poza teczkami zawierającymi dokumenty danych spraw. Można przypuszczać, iż mogłoby to się odbywać w jakichś teczkach, specjalnie do przechowywania takich spisów założonych i prowadzonych.

${ }^{63}$ Omawiana tu instrukcja kancelaryjna niestety nie precyzuje, pisma jakich typów spraw należało ewidencjonować w rejestrze specjalnym. 
sprawie, daty wejścia pisma, nadawcy, daty i znaku sprawy, widniejących na piśmie wpływającym, krótkiego opisu sposobu załatwienia, daty odpowiedzi, ewentualnych uwag. Pisma spraw ewidencjonowanych w rejestrach specjalnych miały nosić oznaczenia, składające się ze skrótu nazwy wydziału, znaku akt oraz kolejnego numeru z rejestru specjalnego bądź właściwej litery z kartoteki alfabetycznej ${ }^{64}$. Choć instrukcja tego nie precyzuje, jednak można domniemywać, iż w przypadku teczek takich spraw również należało prowadzić w nich spisy spraw (określone załącznikiem numer 2), co z kolei skutkować powinno stosownym uzupełnieniem zapisu znaku sprawy. Drugim wyjątkiem miał być arkusz zbiorczy, zakładany w celu rejestracji odpowiedzi na zapytania typu ankietowego. Arkusz taki miał mieć postać tabeli, z rubrykami: znak sprawy, nazwa departamentu i wydziału, wyznaczony na nadesłanie odpowiedzi termin, krótki opis przedmiotu sprawy, nadawca, data wejścia odpowiedzi, daty ewentualnych ponagleń, uwagi (wzór numer 4). Do chwili nadejścia wszystkich przewidywanych odpowiedzi, arkusz zbiorczy należało przechowywać w teczce spraw terminowych, których dotyczył trzeci wyjątek. Mianowicie akta spraw terminowych (czyli oczekujących na odpowiedź w określonym terminie) miały być czasowo przechowywane w odrębnych, specjalnie do tego celu przeznaczonych teczkach i rejestrowane w terminarzu. Jego postać definiował załącznik numer 5, który w nagłówku miał miejsce na zapisanie miesiąca i roku, poniżej rubryki odpowiadające każdemu dniowi tegoż miesiąca.

Tego paragrafu dotyczył drugi fragment wspomnianego już wyżej pisma z dnia 14 listopada 1945 r. (uzupełniającego - jak wspomniano - treść instrukcji kancelaryjnej $)^{65}$. To uzupełnienie dotyczyło postaci znaku sprawy, który powinien zawierać także skrót nazwy departamentu.

Następny - piąty - paragraf omawiał dopuszczalne formy pisemnych załatwień spraw (miały być to załatwienie odręczne, wstępne brulionowe i bezpośrednie czystopisowe) oraz graficzną postać dwóch pierwszych. Dla załatwień odręcznych - w przypadkach, gdy niezbędne było zachowanie w aktach treści pisma wchodzącego - instrukcja zawierała wzór wyciągu do akt (załącznik numer 6), inny wzór (numer 7) określić miał kształt druku do sporządzania brudnopisów odpowiedzi. Paragraf kolejny dotyczył podpisywania pism oraz ich daty. I tak pisma załatwione odręcznie oraz załatwione bezpośrednio miał podpisać referent rozpatrujący daną sprawę, zaś na czystopisach sporządzanych

${ }^{64}$ Zapis ten wyraźnie wskazuje, iż dla akt takich spraw powinny być z góry przewidziane w wykazie akt (i następnie prowadzone) odrębne teczki.

65 AAN, MRiRR, sygn. 249, s. 35-36. 
z brudnopisu - miało być umieszczane nazwisko aprobanta, wraz z klauzulą zgodności. Zasada ta nie dotyczyła pism kierowanych do Prezydenta, Prezesa Rady Ministrów, szefa Najwyższej Izby Kontroli, innych ministerstw i urzędów centralnych, marszałków Sejmu i Senatu, pism o charakterze dokumentu, pism zawierających polecenia wypłaty, które mogli podpisywać wyłącznie wyznaczeni do tego pracownicy Ministerstwa. Datę na piśmie miał obowiązek nanieść referent rozpatrujący sprawę, w wypadku pism sporządzanych z brudnopisu umieszczana być miała data zaaprobowania treści brudnopisu.

Kwestie techniczne przepisywania brulionów omawiał siódmy paragraf, kwestie wysyłki - paragraf ósmy. Ekspedycję prowadziła kancelaria główna Ministerstwa, odnotowując na brulionach fakt wysyłki, następnie zwracając owe bruliony właściwym komórkom organizacyjnym urzędu. Korespondencja wysyłana za pośrednictwem poczty rejestrowana być miała w pocztowej książce nadawczej ${ }^{66}$, telegramy dostarczane miały być do urzędu telegraficznego za pokwitowaniem w książce telegramów (określonej wzorem numer 8, z rubrykami na zanotowanie znaku sprawy, daty i godziny nadania, nazwy i adresu odbiorcy), wreszcie korespondencja miejscowa miała być przez nich kwitowana w książce doręczeń (wzór numer 9, umożliwiający odnotowanie znaku sprawy, daty i godziny wysłania, adresu odbiorcy, daty i godziny odbioru).

W omawianym okresie używano pieczątki kancelaryjnej, posiadającej pola „Przepisano dn...194...r., Sprawdzono ...194...r.”67 Ponadto wykorzystywano dwa wzory pieczątek do oznaczania ekspedycji korespondencji. Pierwsza - używana w latach 1945 i 1946 - posiadała nagłówek treści „Ministerstwo Rolnictwa i R. R., Ekspedycja” oraz pole „wysłano...”, umożliwiające ręczne wpisanie daty ${ }^{68}$. W latach 1946-1948 stosowana była pieczęć wzoru „Ministerstwo Rolnictwa i Reform Rolnych, Ekspedycja, ...wysłano”, w której datę wysłania pisma nanosił automatyczny datownik ${ }^{69}$.

Kwestie przechowywania akt spraw ostatecznie zakończonych, niepotrzebnych już w pracy bieżącej, regulował paragraf dziewiąty omawianej instrukcji. Teczki aktowe z taką dokumentacją należało z komórek organizacyjnych przekazywać do składnicy akt kancelarii głównej Ministerstwa, podobnie wykresy,

${ }^{66}$ Instrukcja nie podaje wzoru takiej książki nadawczej, zapewne był to standardowy druk Poczty Polskiej.

${ }^{67}$ Przykładowo - AAN, MRiRR, sygn. 1459, teczka bez paginacji. Pieczątka tego wzoru stosowana była od początków $1945 \mathrm{r}$.

${ }^{68}$ Przykładowo - tamże, sygn. 1389, teczka bez paginacji. Również ta pieczątka stosowana była od początków $1945 \mathrm{r}$.

${ }^{69}$ Przykładowo - tamże, sygn. 1851, nlb. 
mapy i plany oraz inną dokumentację dużoformatową, opakowaną papierem i zaopatrzoną w stosowny opis zawartości. Przekazanie powinno odbywać się na podstawie wykazu zdawczo-odbiorczego, określonego wzorem numer 10 (posiadającego nagłówek do zapisania nazw departamentu i wydziału, kolejnego numeru wykazu z księgi wykazów zdawczo-odbiorczych składnicy akt, daty przekazania oraz część tabelaryczną, z rubrykami na zapisanie znaku akt, tytułu akt, ilości tomów, dat skrajnych, ewentualnych uwag). Teczki w wykazie powinny być spisane w porządku wykazu akt, to jest w kolejności działów głównych i poddziałów. Poszczególne wykazy należało w składnicy rejestrować we wspomnianej księdze wykazów zdawczo-odbiorczych, opisanej załącznikiem numer 11 (posiadać miała rubryki na wpisanie kolejnego numeru porządkowego, daty przyjęcia akt, nazwy komórki organizacyjnej, przekazującej swoje akta, ilości tomów, ewentualnych uwag). Numer porządkowy z tej księgi należało nanieść do stosownej rubryki nagłówka wykazu zdawczo-odbiorczego oraz na każdą teczkę i paczkę, objętą tym wykazem. Wypożyczenie akt ze składnicy odbywać się powinno na podstawie pokwitowania (określonego wzorem numer 12).

Paragraf dziesiąty omawiał obieg akt w Ministerstwie, jego graficzną ilustrację przedstawiał załącznik numer 14. Poszczególne etapy obiegu nie mogły być rejestrowane w żadnych dodatkowych - nie przewidzianych treścią przepisów kancelaryjnych - pomocach ewidencyjnych. Obieg pism wewnątrz urzędu miał więc odbywać się w teczkach, z naklejonym arkuszem, umożliwiającym zapisanie na wstępie znaku akt, a dalej odnotowywanie kolejnych punktów zatrzymania i czynności w nich dokonywanych ${ }^{70}$, przedstawionym na załączniku numer 13 . Obieg pism miał odbywać się z reguły bez pokwitowań ${ }^{71}$.

Dwa ostatnie paragrafy instrukcji dotyczyły akt spraw tajnych i poufnych (tryb postępowania z tą dokumentacją miał zostać uregulowany odrębnymi przepisami ${ }^{72}$ ) oraz wykazów ruchu spraw - czyli kwartalnych zestawień ogólnej ilości spraw rozpatrywanych w poszczególnych komórkach organizacyjnych Ministerstwa oraz ilości spraw zaległych.

Paragraf czwarty normatywu „Ministerstwo Rolnictwa i Reform Rolnych. Instrukcja Kancelaryjna" omawiał kwestie stosowania wykazu akt w pracy

70 Instrukcja nie precyzuje, jakie informacje należało wpisywać do tego arkusza. Można jedynie domniemywać, iż mowo - przykładowo - o odnotowanie przydziału sprawy, przekazaniu brulionu do akceptacji i jej uzyskaniu, przekazaniu do działu maszyn, sporządzeniu czystopisu i jego sprawdzeniu, ekspedycji.

${ }^{71}$ Zapis ten wskazuje, iż zapewne dla pism określonych typów spraw dopuszczono możliwość dodatkowej kontroli obiegu, właśnie w postaci pokwitowań wewnętrznych.

72 Nastąpiło to jednak dopiero w $1948 \mathrm{r}$. 
biurowej Ministerstwa. W archiwaliach Wydziału Organizacyjnego Ministerstwa zachowały się rzeczowe wykazy akt komórek organizacyjnych urzędu z lat 1946-1948 (wprawdzie niektóre dokumenty nie mają naniesionej daty, jednak fakt iż są spięte $\mathrm{w}$ jednym pliku $\mathrm{z}$ datowanymi, pozwala w ich przypadku przyjąć datację analogiczną z pozostałymi dokumentami danego pliku). Niekiedy są to wersje robocze (z dopiskami i uzupełnieniami) oraz końcowe (już z uwzględnionymi poprawkami), niekiedy zaś jest kilka kolejnych wersji redakcyjnych jednego wykazu z naniesionymi na czystopis ewentualnymi poprawkami, niekiedy wykazy zachowały się w jednej wersji.

Wykazy te określa się mianem wykazów strukturalno-rzeczowych. Opierają się one na aktualnie obowiązujących w urzędzie schemacie organizacyjnym oraz szczegółowym podziale czynności jego komórek organizacyjnych, wymieniają po kolei wszystkie komórki (wydziały i referaty), dla których w zasadzie przygotowuje się odrębne wykazy, układające akta według z góry ustalonego podziału na grupy przedmiotowe. Wadami wszystkich tego typu wykazów są konieczność dostosowywania ich do każdorazowej wewnętrznej reorganizacji instytucji czy zmiany kompetencji jej komórek oraz powtarzanie się w wykazach różnych wydziałów i referatów identycznych bądź bardzo zbliżonych do siebie tematycznie grup spraw czy pojedynczych teczek. Zaletą natomiast - pewna ich autonomia, pozwalająca wykorzystywać poszczególne elementy składowe wykazu bez naruszania jego innych części.

I tak zachowały się wykazy akt kilku komórek Gabinetu Ministra ${ }^{73}$, kilku komórek Departamentu Finansowego (Ekonomicznego) ${ }^{74}$, Departamentu Państwowych Gospodarstw i Zakładów Rolnych ${ }^{75}$, Departamentu Wodno-Melioracyjnego $^{76}$, Departamentu Produkcji Rolnej ${ }^{77}$, Departamentu Funduszu Ziemi ${ }^{78}$, Departamentu Przebudowy Ustroju Rojnego ${ }^{79}$, Departamentu Weterynarii80, Departamentu Oświaty Rolniczej ${ }^{81}$, Biura Personalnego ${ }^{82}$, Biura Kontroli ${ }^{83}$, Biura

\footnotetext{
73 AAN, MRiRR, sygn. 253, s. 12, 14; sygn. 4994, s. 48-50.

74 Tamże, sygn. 253, s. 6, 7; sygn. 4994, s. 5, 61, 62.

75 Tamże, sygn. 253, 16-25, 95.

76 Tamże, sygn. 253, s. 27-34, 97, 98; sygn. 4994, s. 32-34, 74-76, 78-80.

77 Tamże, sygn. 253, s. 55-77; sygn. 4994, s. 52-59.

78 Tamże, sygn. 253, s. 79-88; sygn. 4994, s. 13-18, 20-25, 27-31.

79 Tamże, sygn. 4994, s. 6-12.

80 Tamże, sygn. 4994, s. 64-73, 85-93.

81 Tamże, sygn. 4994, s. 36-40.

82 Tamże, sygn. 253, s. 1-4.

83 Tamże, sygn. 253, s. 89-94; sygn. 4994, s. 96.
} 


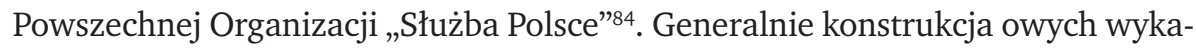
zów była zgodna z zapisami wspomnianego paragrafu przepisów kancelaryjnych Ministerstwa. Poszczególne departamenty i inne samodzielne biura powinny posiadać swoje symbole literowe, działy spraw (czyli większe tematycznie grupy spraw bądź referaty w ramach wydziału) oznaczane miały być kolejnymi cyframi rzymskimi, prowadzone zaś w ich ramach teczki miały być oznaczane kolejnymi cyframi arabskimi. W kilku przypadkach przewidywano jeszcze podteczki, oznaczane kolejnymi małymi literami alfabetu, ewentualnie zakładano prowadzenie odrębnych teczek dla każdego województwa. Instrukcja kancelaryjna zalecała ponadto umieszczanie w znaku sprawy symbolu wydziału, rozpatrującego w ramach swych statutowych obowiązków ową sprawę. W przypadku omawianych tu wykazów przyjęto różne rozwiązania: niekiedy poszczególne wydziały oznaczane być miały cyframi arabskimi, niekiedy symbolami zbudowanymi z liter ${ }^{85}$.

Analiza dokumentów (widniejących na nich oznaczeń) potwierdza stosowanie do rejestracji pism i spraw w Ministerstwie Rolnictwa i Reform Rolnych w omawianym okresie (czyli od przełomu lat 1945 i 1946 do końca roku 1948) tak zbudowanych wykazów akt. I tak na pismach Gabinetu Ministra widniały oznaczenia postaci - przykładowo „GM/1.V.2/8”86 czy w wersji z dwoma cyframi daty rocznej „GM/1-V-3/14/46"87. Z kolei dokumenty Departamentu Finansowego (Ekonomicznego) nosiły oznaczenia - przykładowo „Ek I-1-19”88, „Ek VI-5-1”89 czy po zmianie nazwy Departamentu „Fin.1-I-2/9”90. W dwóch wersjach nanoszono symbole na pismach Departamentu Przebudowy Ustroju Rolnego: „UR/4.II.3/72"91 bądź z dwoma ostatnimi cyframi daty rocznej „UR/2.X.0/6/48”92, zaś w jednej wersji na pismach Departamentu Oświaty

${ }^{84}$ Tamże, sygn. 253, s. 36-42.

85 Jedynym odstępstwem od tych zaleceń jest projekt wykazu akt dla Wydziału Torfowego Departamentu Wodno-Melioracyjnego, w którym teczka pism spraw ogólnych Wydziału miała posiadać symbol „O”, zaś teczki spaw szczegółowych - oznaczane kolejnymi cyframi arabskimi - miał poprzedzać symbol „OD”. I o ile litera „O” może pochodzić od „ogólny / ogólne”, to trudno jednoznacznie rozstrzygnąć, co mógł oznaczać skrót „OD” („dział / dziedzina”?); tamże, sygn. 4994, s. 32.

86 Tamże, sygn. 115, nlb.

87 Tamże.

88 Tamże, sygn. 82, s. 46.

89 Tamże, sygn. 1138, nlb.

90 Tamże, sygn. 597, nlb.

91 Przykładowo - tamże, sygn. 1713, s. 15.

${ }^{92}$ Przykładowo - tamże, s. 140. 
Rolniczej: „Nr.OR/5/III/1/4”93. Jak więc widać, oznaczenie składało się każdorazowo z symbolu literowego komórki organizacyjnej rangi departamentu czy samodzielnego biura, cyfrowego bądź literowego symbolu wydziału, symbolu tematycznego działu spraw merytorycznych przez ten wydział rozpatrywanych (również mógł być literowy albo cyfrowy), symbolu teczki, numeru sprawy $\mathrm{w}$ ramach danej teczki, które ewentualnie uzupełniały dwie ostatnie cyfry daty rocznej. Różnice pomiędzy takimi oznaczeniami stanowiły jedynie znaki, oddzielające poszczególne elementy (były nimi kropki, myślniki i prawe ukośniki, niekiedy stosowane zamiennie). Zapewne trwały cały czas prace nad ujednoliceniem kształtu owych wydziałowych wykazów akt, o czym świadczą zachowane - wspomniane wyżej - różne wersje robocze ${ }^{94}$.

Wspomniana analiza dokumentów Ministerstwa pozwala dostrzec także inne detale pracy kancelaryjnej urzędu i metod rejestracji pism, wymienione w samym tekście przepisów biurowych urzędu oraz w datowanym 14 listopada 1945 r. uzupełnieniu podstawowego tekstu. Mowa o pomocy ewidencyjnej, nazwanej rejestrem, prowadzonej w departamentach Ministerstwa, wspólnej dla wszystkich podległych im wydziałów. Rejestr ten pełnił rolę tradycyjnego dziennika podawczego, w którym rejestrowano pisma wpływające z kancelarii głównej Ministerstwa, rozdzielone tam do poszczególnych departamentów i samodzielnych biur urzędu, według ich kompetencji merytorycznych. Numer kolejny z rejestru departamentowego nanoszono niekiedy w rubryce pieczęci wpływu kancelarii głównej ${ }^{95}$, niekiedy - o ile takowa była w danej komórce organizacyjnej Ministerstwa była stosowane - w rubryce pieczątki wpływu komórki organizacyjnej ${ }^{96}$, niekiedy zaś po prostu w wolnym miejscu pisma ${ }^{97}$. Numerowi z rejestru zazwyczaj towarzyszył symbol literowy komórki organizacyjnej Ministerstwa, sporadycznie także dwie ostatnie cyfry daty rocznej ${ }^{98}$. Dalej następowała rejestracja w spisie spraw wydziału i nadanie właściwego oznaczenia symbolem wynikającym z wykazu akt danej komórki. Nieznacznie

93 Przykładowo - tamże, sygn. 114, s. 49.

${ }^{94}$ O trwających wciąż tych pracach pisał między innymi w kwietniu 1947 r. do Biura Organizacji i Spraw Osobowych Prezydium Rady Ministrów kierownik Departamentu Ogólnego Ministerstwa; tamże, sygn. 4997, s. 28.

95 Przykładowo - tamże, sygn. 84, s. 56.

96 Przykładowo - tamże, sygn. 27, s. 121.

97 Przykładowo - tamże, sygn. 84, s. 93.

98 Wskazanie daty rocznej przy numerze rejestru odnaleziono tylko na pismach zadekretowanych do Departamentu Przebudowy Ustroju Rolnego i tam zarejestrowanych (przykładowo - tamże, sygn. 1715, s. 158, 205, 206). 
odmienną procedurę stosowano $\mathrm{w}$ Biurze Kontroli, gdzie numer z rejestru był łączony ze znakiem sprawy - przykładowo „L. B.K. I/18-7-1002”99 czy „Nr. B.K. I/18-7-1255”100, gdzie liczby „1002” oraz „1255” były właśnie numerami z rejestru tego Biura.

Kancelaria Ministerstwa Rolnictwa i Reform Rolnych (w omawianym tu okresie, czyli w latach 1945-1948 urzędu samodzielnego, zaś w roku 1944 jednego z resortów Polskiego Komitetu Wyzwolenia Narodowego) nie przeszła dość typowej dla kancelarii urzędów państwowych tego okresu drogi. Zazwyczaj bowiem rejestracja pism opierała się początkowo na typowym dzienniku podawczym ze skorowidzami, wspólnym dla wszystkich komórek organizacyjnych i prowadzonym przez kancelarię główną urzędu, w następnym zaś etapie dzienniki podawcze były wprowadzane w poszczególnych komórkach organizacyjnych urzędu, a przechowywanie akt spraw ostatecznie zamkniętych nadal odbywało się na podstawie rzeczowych planów akt. Z czasem wdrażano (niekiedy tylko w wybranych komórkach urzędu, niekiedy od razu we wszystkich) przepisy oparte częściowo na regulacjach przedwojennych (na ramowych „Przepisach kancelaryjnych dla administracji rządowej” z dnia 24 sierpnia 1931 r.), czyli zazwyczaj po wstępnej rejestracji korespondencji w kancelarii głównej w jakiejś pomocy ewidencyjnej (najczęściej w formie zbliżonej do dziennika podawczego) miała być następnie właściwie rejestrowana i oznaczana w oparciu o niejednolite rzeczowe strukturalne wykazy akt, przygotowywane przez poszczególne komórki organizacyjne, przy czym najczęściej taki model pracy kancelaryjnej ustanawiany był dopiero po opublikowaniu wzorcowej instrukcji kancelaryjnej dla ministerstw i urzędów centralnych, ogłoszonej stosownym okólnikiem prezesa rady ministrów z dnia 5 lutego $1948 \mathrm{r}$.

W początkowym okresie kancelaria Ministerstwa Rolnictwa i Reform Rolnych funkcjonowała oczywiście również w oparciu o ogólne regulacje, obowiązujące w pracy biurowej Polskiego Komitetu Wyzwolenia Narodowego, jednak już z dniem 1 grudnia 1945 r. weszły w Ministerstwie w życie własne przepisy kancelaryjne: „Ministerstwo Rolnictwa i Reform Rolnych. Instrukcja Kancelaryjna” (zachowane egzemplarze instrukcji nie posiadają daty dziennej), uzupełnione dokumentem, zatytułowanym „Uzupełnienie Instrukcji Kancelaryjnej Ministerstwa Rolnictwa i Reform Rolnych", a datowanym na dzień 14 listopada 1945 r. ${ }^{101}$

99 Tamże, sygn. 774, s. 1.

100 Tamże, s. 69.

101 Regulacje te obowiązywały do końca 1948 r., zastąpione zostały na mocy stosownych zapisów zarządzenia wewnętrznego z dnia 30 czerwca 1948 r. w sprawie 
Kancelaria ogólna Ministerstwa nie prowadziła żadnych pomocy ewidencyjnych, rozdzielała tylko wpływającą do urzędu korespondencję do poszczególnych departamentów i samodzielnych biur, według ich kompetencji merytorycznych. W departamentach i pozostałych samodzielnych komórkach następowała rejestracja w pomocy ewidencyjnej, nazwanej rejestrem (który pełnił rolę tradycyjnego dziennika podawczego ${ }^{102}$ ), prowadzonej wspólnie dla wszystkich wydziałów danego departamentu. Dopiero w tych wydziałach następowała właściwa rejestracja w spisie spraw wydziału i nadanie oznaczenia symbolem wynikającym z rzeczowego strukturalnego wykazu akt danej komórki ${ }^{103}$.

W efekcie więc już od 1945 r. kancelaria Ministerstwa opierała swoje funkcjonowanie na nowoczesnym systemie rejestracji spraw nie $\mathrm{w}$ dzienniku podawczym (ten był wprawdzie stosowany, ale tylko to wstępnego ewidencjonowania korespondencji), a w oparciu o rzeczowy wykaz akt. Jednocześnie było to nawiązaniem do okresu dwudziestolecia międzywojennego, kiedy to $\mathrm{w}$ pracy biurowej poprzednika Ministerstwa Rolnictwa i Reform Rolnych (również noszącego od 1932 r. taką nazwę) weszły w życie „Przepisy kancelaryjne dla zarządu centralnego Ministerstwa Rolnictwa i Reform Rolnych", stanowiące załącznik do pisma okólnego z dnia 16 lipca 1932 r. ${ }^{104}$, nakazującego aby od dnia 1 stycznia $1933 \mathrm{r}$. wszystkie wydziały urzędu prowadziły rejestrację spraw właśnie w oparciu o rzeczowe wykazy akt.

\section{Bibliografia}

Barszcz, Anna. Prezydium Rady Ministrów i Urząd Rady Ministrów jako twórcy państwowego zasobu archiwalnego (1945-1996). Warszawa: Naczelna Dyrekcja Archiwów Państwowych, 2014.

wprowadzenia w życie nowej instrukcji kancelaryjnej; ostatecznym terminem wejścia z życie nowych regulacji był dzień 1 stycznia 1949 r.; tamże, sygn. 4997, s. 234-236; tekst nowych przepisów zob. tamże, sygn. 249, s. 155-206.

102 Sam tekst przepisów nic o tym nie wspomina, nie można też - ze względu na stan zachowania akt Ministerstwa - stwierdzić, czy do owych rejestrów departamentowych prowadzono jakieś skorowidze alfabetyczne. Można jedynie przypuszczać, iż ze względu na ilość wpływającej korespondencji i prowadzonych przez urząd spraw, takie pomocy ewidencyjne mogły jednak być tworzone i prowadzone.

103 Warto dodać, iż niektóre komórki organizacyjne Ministerstwa opracowały i wdrożyły własne rzeczowe wykazy akt już w marcu 1945r. (AAN, MRiRR, sygn. 4994, s. 60).

104 AAN, Ministerstwo Rolnictwa i Reform Rolnych w Warszawie 1918-1939, sygn. 15 , s. 1-35. 
Brzoza, Czesław. Reforma rolna w województwie krakowskim, 1945-1948. Prace Komisji Historycznej, nr 51. Wrocław: Zakład Narodowy im. Ossolińskich, 1988.

Dąbrowski, Adam Grzegorz. „Kancelaria Ministerstwa Skarbu w Warszawie w latach 1944-1950". Archiwa - Kancelarie - Zbiory, nr 9(11) (2018): 149-78. https://doi. org/10.12775/AKZ.2018.008.

Dąbrowski, Adam Grzegorz. „Przepisy kancelaryjne Ministerstwa Administracji Publicznej z lat 1945-1950". Teki Archiwalne. Seria Nowa 7(29) (2003): 63-74.

Dąbrowski, Adam Grzegorz. „Przepisy kancelaryjne Ministerstwa Ziem Odzyskanych z lat 1945-1949". Archeion 117 (2016): 387-405.

Degen, Robert. „O usprawnienie kancelarii Ministerstwa Administracji Publicznej. Projekt Mariana Cieszyńskiego z grudnia 1947 roku”. Krakowski Rocznik Archiwalny 11 (2005): 203-15.

Degen, Robert. „Sposoby usprawniania pracy biurowej w polskich urzędach w latach 1945-1950". W Dzieje biurokracji na ziemiach polskich, t.1, zredagowali Artur Górak, Ireneusz Łuć, i Dariusz Magier, 537-551. Radzyń Podlaski: Radzyńskie Stowarzyszenie Inicjatyw Lokalnych : Radzyńskie Towarzystwo Naukowe (Libra), 2008.

Filipczak, Teresa. Kancelaria Sejmu i Rady Państwa oraz archiwum w latach [1944] 1952-1989. Warszawa: Naczelna Dyrekcja Archiwów Państwowych. Departament Organizacji i Udostępniania. Wydział Popularyzacji i Wydawnictw, 2015.

Iwaniak, Stefan. Reforma rolna $w$ województwie kieleckim $w$ latach 1944-1945. Warszawa: Ludowa Spółdzielnia Wydawnicza, 1975.

Klonowska, Weronika. „Próby usprawnienia kancelarii (biurowości) urzędów administracji centralnej w latach 1945-1952." Acta Universitatis Nicolai Copernici, Historia 8 (1973): 189-204.

Kozaczka, Marian. „Reforma rolna w ordynacji przeworskiej w latach 1944-1945”. Rocznik Przemyski 4 (1999): 117-26.

Kozaczka, Marian. „Reforma rolna w ordynacji zamojskiej 1944-1945”. Prace Historyczno-Archiwalne 9 (2000): 173-85.

Kozaczka, Marian. „Reforma rolna w ordynacji kozłowieckiej 1944-1945”. Rocznik Historyczno-Archiwalny 15 (2001): 95-107.

Krupska, Zofia. „Zarządzanie dokumentacją aktową w naczelnych organach bezpieczeństwa państwa i porządku publicznego w latach 1944-1990”. W W kręgu „teczek”. $Z$ badań nad zasobem i funkcjami archiwum Instytutu Pamięci Narodowej, zredagowali Jerzy Bednarek i Paweł Perzyna, 115-28. Łódź: Instytut Pamięci Narodowej - Komisja Ścigania Zbrodni przeciwko Narodowi Polskiemu; Toruń: Wydawnictwo Adam Marszałek, 2007.

Kubisiak, Krzysztof. „Reforma rolna w województwie łódzkim”. Piotrkowskie Zeszyty Historyczne 6 (2004): 239-50.

Ministerstwo Rolnictwa i Reform Rolnych w Warszawie 1918-1939. Archiwum Akt Nowych, Warszawa.

Ministerstwo Rolnictwa i Reform Rolnych w Warszawie 1945-1951. Archiwum Akt Nowych, Warszawa. 
Pękul, Grzegorz. „Reforma rolna w gminie Łochów”. Rocznik Historyczny Muzeum Historii Polskiego Ruchu Ludowego 29 (2013): 113-28.

Polski Komitet Wyzwolenia Narodowego w Lublinie 1944 [1945-1953]. Archiwum Akt Nowych, Warszawa.

Słabek, Henryk. Dzieje polskiej reformy rolnej 1944-1948. Biblioteka Wiedzy Historycznej. Historia Polski. Warszawa: Wiedza Powszechna, 1972.

Słabek, Henryk. Polityka agrarna PPR: geneza, realizacja, konsekwencje. 2. wyd. Warszawa: Książka i Wiedza, 1978.

Słabek, Henryk. Przebudowa ustroju rolnego w Wielkopolsce i na Pomorzu 1945-1948. Poznań: Wydawnictwo Poznańskie, 1968.

Stasiak, Piotr. „Reforma rolna w powiecie kutnowskim. Część 1: rok 1945”. Kutnowskie Zeszyty Regionalne 13 (2009): 89-114.

Stasiak, Piotr. „Reforma rolna w powiecie kutnowskim. Część 2: spółdzielnie produkcyjne do 1952 r., Kutnowskie Zeszyty Regionalne 14 (2010): 147-202.

„Ustawa z dnia 11 sierpnia 1923 r. o zakresie działania Ministra Reform Rolnych i organizacji urzędów i komisji ziemskich.” Dziennik Ustaw Rzeczypospolitej Polskiej, nr 90, poz. 706 (1923).

„Ustawa z dnia 21 lipca 1944 r. o utworzeniu Polskiego Komitetu Wyzwolenia Narodowego." Dziennik Ustaw Rzeczypospolitej Polskiej, nr 1, poz. 1 (1944).

„Dekret Polskiego Komitetu Wyzwolenia Narodowego z dnia 6 września 1944 r. o przeprowadzeniu reformy rolnej." Dziennik Ustaw Rzeczypospolitej Polskiej, nr 4, poz. 17 (1944).

„Ustawa z dnia 31 grudnia 1944r. o powołaniu Rządu Tymczasowego Rzeczypospolitej Polskiej." Dziennik Ustaw Rzeczypospolitej Polskiej, nr 19, poz. 99 (1944).

„Ustawa z dnia 26 maja 1951 r. o organizacji władz naczelnych w dziedzinie rolnictwa.” Dziennik Ustaw Rzeczypospolitej Polskiej, nr 30, poz. 236 (1951).

Wielgosz, Anna. „Reforma rolna w powiecie łukowskim 1944-1946”. Roczniki Wyższej Szkoty Biznesu i Administracji w Łukowie 4 (2008): 409-431. 
